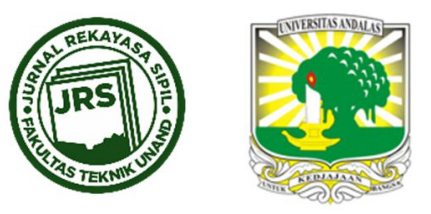

\title{
PENGARUH PENERAPAN SNI 1726:2019 TERHADAP DESAIN STRUKTUR RANGKA MOMEN BETON BERTULANG DI INDONESIA
}

\author{
AHMAD SOBAH NURUL SODIK ${ }^{1^{*}}$, RELLY ANDAYANI ${ }^{2}$ \\ ${ }^{1}$ Program Magister Teknik Sipil, Universitas Gunadarma, Jakarta, Indonesia \\ ${ }^{2}$ Departemen Teknik Sipil, Universitas Gunadarma, Jakarta, Indonesia \\ *Corresponding author: $₫$ a.sobah_ns@student.gunadarma.ac.id
}

Naskah diterima : 9 September 2020. Disetujui: 16 Februari 2021

\begin{abstract}
ABSTRAK
Telah diterbitkan peraturan gempa yang terbaru, yaitu tata cara perencanaan ketahanan gempa untuk struktur gedung dan non gedung SNI 1726:2019 menggantikan peraturan gempa sebelumnya, SNI 1726:2012. Dalam penelitian ini spektra desain yang ada dalam SNI 1726:2019 dibandingkan dengan spektra desain dalam SNI 1726:2012 dengan mengambil sampling 21 kota besar yang dianggap mewakili seluruh wilayah Indonesia. Dari hasil perbandingan tampak sebagian besar mengalami kenaikan walaupun tidak sedikit yang mengalami penurunan dan ada pula yang tetap. Penerapan faktor amplifikasi $\mathrm{F}_{\mathrm{a}}$ menurut SNI 1726:2019 menyebabkan adanya fenomena anomali di daerahdaerah rawan gempa, dimana nilai spektra desain untuk perioda pendek di situs Tanah Lunak (SE) dapat lebih rendah daripada nilai untuk Tanah Sedang (SD) dan Tanah Keras (SC). Fenomena anomali tersebut terjadi di kota-kota dengan $\mathrm{S}_{\mathrm{S}}$ di atas $0,75 \mathrm{~g}$. Penelitian dilanjutkan dengan melakukan studi komparasi dengan membandingkan besaran gaya gempa yang dihitung menggunakan SNI 1726:2012 dan SNI 1726:2019 terhadap suatu sampel model struktur gedung yang diasumsikan terletak di Jakarta pada kondisi tanah lunak (SE). Terjadi kenaikan base shear desain pada gedung yang dihitung menggunakan SNI 1726:2019 dibandingkan gedung yang dihitung menggunakan SNI 1726:2012 sebesar 128,93\% untuk arah x dan 131,23\% untuk arah y. Sampel model struktur gedung memiliki level kinerja life safety jika dievaluasi terhadap peraturan gempa SNI 1726:2012 dan mengalami penurunan kinerja dari level life safety ke collapse prevention jika dievaluasi terhadap gempa peraturan baru, SNI 1726:2019.
\end{abstract}

Kata kunci : SNI 1726:2012; SNI 1726:2019; Spektra Desain; Evaluasi Kinerja; Pushover Analysis jalur

\section{PENDAHULUAN}

Dalam 7 tahun terakhir ini, beberapa wilayah di Indonesia mengalami gempa bumi yang cukup besar, di antaranya yaitu 11 April 2012 di Aceh (8,5 SR) yang juga menyebabkan tsunami kecil dengan ketinggian $1 \mathrm{~m}$ di wilayah Nias dan $80 \mathrm{~cm}$ di Meulaboh, 7 Desember 2016 di Pidie Jaya (6,5 SR) sebagai salah satu gempa yang melahirkan sesar baru, 29 Juli dan 5 Agustus 2018 berturut-turut di Lombok (6,4 SR dan 7,0 SR), dan 28 September 2018

DOI : https://doi.org/10.25077/jrs.17.1.1-12.2021

Attribution-NonCommercial 4.0 International. Some rights reserved 
di Dongala dan Palu (7,4 SR) gempa yang juga menyebabkan terjadinya tsunami serta peristiwa likuefaksi. Gempa-gempa tersebut telah menyebabkan ribuan korban jiwa, keruntuhan dan kerusakan ribuan infrastruktur dan bangunan, serta dana trilyunan rupiah untuk rehabilitasi dan rekonstruksi. Hal ini disebabkan karena banyak gedung yang tidak dapat mempertahankan strukturnya ketika gempa terjadi.

Menyikapi hal di atas, pada tanggal 17 Desember 2019 pemerintah lewat Badan Standardisasi Nasional menerbitkan peraturan gempa Indonesia yang baru SNI 1726:2019 (Badan Standardisasi Nasional, 2019) dengan tujuan untuk memperbarui peraturan gempa Indonesia sebelumnya, SNI 1726:2012 (Badan Standardisasi Nasional, 2012) yang dianggap sudah tidak sesuai dengan keadaan sekarang, sehingga gedung yang akan dibangun nantinya dapat mempertahankan strukturnya dengan lebih baik ketika gempa terjadi.

SNI 1726:2019 didasarkan pada studi yang dilakukan oleh Irsyam et al. (2017) dan telah mengacu pada standar dan peraturan terkini di negara maju, khususnya Amerika Serikat (AS), yaitu ASCE/SEI 7-16 (American Society of Civil Engineers, 2017) dan FEMA 1050 (Building Seismic Safety Council, 2015).

Akibat diterapkannya SNI 1726:2019, banyak daerah mengalami perubahan spektra desain, apakah kenaikan maupun penurunan seperti hasil penelitian yang telah dilakukan oleh Sutjipto and Sumeru (2019) terhadap 17 kota terpilih. Pada penelitian tersebut juga diketahui adanya fenomena anomali yang terjadi pada besaran spektra desain berdasarkan urutan klasifikasi situs tanah.

Berangkat dari latar belakang tersebut, melalui penelitian ini dilakukan pengembangan sampai pada studi komparasi untuk melihat perubahan besarnya gaya gempa dan level kinerja dari suatu sampel struktur bangunan gedung yang ditempatkan pada salah satu daerah yang mengalami kenaikan nilai spektra desain.

\section{METODOLOGI PENELITIAN}

\subsection{Metode Perolehan Data}

Data parameter respons spektra dalam penelitian ini diperoleh dari aplikasi online Pusat Penelitian dan Pengembangan milik Kementerian Pekerjaan Umum (PuSGen, 2010, 2021), sedangkan data bangunan yang akan digunakan sebagai model studi komparasi didasarkan atas asumsi yang didukung oleh data sekunder dari referensi yang relevan. Bangunan dianalisis sesuai dengan gaya gempa berdasarkan SNI 1726:2012 dan SNI 1726:2019.

\subsection{Metode Penelitian}

Secara garis besar penelitian ini dibagi menjadi 2 sub penelitian yaitu: (1) membandingkan spektrum respons desain SNI 1726:2019 terhadap SNI 1726:2012 untuk beberapa kota di Indonesia; dan (2) melakukan studi komparasi bangunan yang didesain menggunakan SNI 1726:2012 dan SNI 1726:2019.

\subsubsection{Perbandingan Spektra Desain}

Pada sub penelitian ini akan dibandingkan spektrum respons desain atau singkatnya spektra desain dari 21 kota di Indonesia yaitu: Banda Aceh, Medan, Padang, Bengkulu, Palembang, Bandar Lampung, Jakarta, Bandung, Semarang, Yogyakarta, Surabaya, Denpasar, Mataram, Kupang, Makassar, Kendari, Palu, Manado, Ambon, Manokwari dan Jayapura. 
Spektra desain yang dibandingkan adalah spektra desain SNI 1726:2019 terhadap spektra desain SNI 1726:2012 guna mengetahui kota-kota yang mengalami kenaikan maupun penurunan spektra desain.

\subsubsection{Studi Komparasi}

Studi komparasi ini dilakukan dengan tujuan untuk mengetahui seberapa jauh pengaruh penerapan SNI 1726:2019 terhadap desain struktur rangka momen beton bertulangan, dimulai dari besarnya gaya gempa dan kinerjanya akibat pembaruan peraturan.

Sampel model struktur adalah bangunan beton bertulangan dengan sistem rangka pemikul momen. Elemen struktur didesain sesuai dengan gaya dalam yang terjadi berdasarkan SNI 1726:2012. Selanjutnya sampel model struktur akan dievaluasi kinerjanya terhadap gempa SNI 1726:2012 dan SNI 1726:2019 untuk mengetahui seberapa jauh perubahan kinerja akibat diterapkannya peraturan gempa baru.

Analisis gaya gempa untuk perencanaan elemen struktur adalah analisis dinamik linear (spektrum respons). Sedangkan untuk evaluasi kinerja dipakai analisis statik non linear (pushover). Analisis spektrum respons dilakukan dengan dasar SNI 1726:2012 dan SNI 1726:2019, dan untuk analisis pushover dilakukan berdasarkan panduan ATC-40 (Applied Technology Council, 1996).

\section{HASIL DAN PEMBAHASAN}

\subsection{Perbandingan Spektra Desain}

Dengan diterbitkannya SNI 1726:2019, tentu akan mempengaruhi perencanaan bangunan terhadap pembebanan gempa. Untuk itu spektra desain beberapa kota dibandingkan untuk melihat sejauh mana perbedaan spektral respons percepatannya. Perbandingan spektra desain dilakukan untuk 21 kota yang dianggap dapat mewakili seluruh wilayah Indonesia dari Barat sampai ke Timur, dan dari Utara sampai ke Selatan sebagai sampling (Tabel 1).

Tabel 1. Parameter Percepatan Spekta Perioda Pendek dan 1 detik untuk 21 Kota di Indonesia

\begin{tabular}{|c|c|c|c|c|c|c|c|c|c|}
\hline \multirow{2}{*}{ No. } & \multirow{2}{*}{ Kota } & \multicolumn{2}{|c|}{ Koordinat } & \multicolumn{3}{|c|}{ Ss } & \multicolumn{3}{|c|}{$\mathbf{S}_{1}$} \\
\hline & & Lintang & Bujur & $1726: 12$ & $1726: 19$ & Rasio & $1726: 12$ & $1726: 19$ & Rasio \\
\hline 1 & Banda Aceh & 5,5467 & 95,3179 & 1,3590 & 1,5025 & 1,11 & 0,6510 & 0,6000 & 0,92 \\
\hline 2 & Medan & 3,5883 & 98,6702 & 0,5280 & 0,6572 & 1,24 & 0,3330 & 0,3624 & 1,09 \\
\hline 3 & Padang & $-0,9366$ & 100,4037 & 1,3910 & 1,4554 & 1,05 & 0,6000 & 0,6000 & 1,00 \\
\hline 4 & Bengkulu & $-3,8192$ & 102,3165 & 1,1210 & 1,5000 & 1,34 & 0,5050 & 0,6000 & 1,19 \\
\hline 5 & Palembang & $-2,9716$ & 104,7588 & 0,2620 & 0,2933 & 1,12 & 0,1640 & 0,2500 & 1,52 \\
\hline 6 & $\begin{array}{l}\text { Bandar } \\
\text { Lampung }\end{array}$ & $-5,3935$ & 105,2625 & 0,7400 & 0,8651 & 1,17 & 0,3180 & 0,4289 & 1,35 \\
\hline 7 & Jakarta & $-6,2253$ & 106,8087 & 0,6880 & 0,8133 & 1,18 & 0,3010 & 0,3939 & 1,31 \\
\hline 8 & Bandung & $-6,9103$ & 107,6192 & 1,4670 & 1,1826 & 0,81 & 0,4890 & 0,5121 & 1,05 \\
\hline 9 & Semarang & $-6,9957$ & 110,4231 & 1,0110 & 0,8694 & 0,86 & 0,3380 & 0,3768 & 1,11 \\
\hline 10 & Yogyakarta & $-7,7720$ & 110,3532 & 1,0830 & 1,1075 & 1,02 & 0,4070 & 0,5004 & 1,23 \\
\hline 11 & Surabaya & $-7,2979$ & 112,7195 & 0,6660 & 0,7964 & 1,20 & 0,2520 & 0,3444 & 1,37 \\
\hline 12 & Denpasar & $-8,6555$ & 115,2034 & 0,9770 & 0,9579 & 0,98 & 0,3590 & 0,3960 & 1,10 \\
\hline 13 & Mataram & $-8,5937$ & 116,1048 & 0,9590 & 1,0408 & 1,09 & 0,3840 & 0,4057 & 1,06 \\
\hline 14 & Kupang & $-10,1796$ & 123,6079 & 1,1130 & 1,0506 & 0,94 & 0,2950 & 0,3747 & 1,27 \\
\hline
\end{tabular}




\begin{tabular}{llcccccccc}
\hline \multirow{2}{*}{ No. } & \multirow{2}{*}{ Kota } & \multicolumn{2}{c}{ Koordinat } & \multicolumn{3}{c}{$\mathbf{S}_{\mathbf{s}}$} & \multicolumn{3}{c}{$\mathbf{S}_{\mathbf{1}}$} \\
\cline { 3 - 11 } & & Lintang & Bujur & $\mathbf{1 7 2 6 : 1 2}$ & $\mathbf{1 7 2 6 : 1 9}$ & Rasio & $\mathbf{1 7 2 6 : 1 2}$ & $\mathbf{1 7 2 6 : 1 9}$ & Rasio \\
\hline 15 & Makassar & $-5,1512$ & 119,4260 & 0,3150 & 0,2206 & 0,70 & 0,1420 & 0,1078 & 0,76 \\
\hline 16 & Kendari & $-3,9819$ & 122,5055 & 0,8280 & 0,6868 & 0,83 & 0,3310 & 0,2002 & 0,60 \\
\hline 17 & Palu & $-0,9185$ & 119,9063 & 2,1800 & 1,5000 & 0,69 & 0,7680 & 0,6000 & 0,78 \\
\hline 18 & Manado & 1,4637 & 124,8408 & 1,0350 & 1,0526 & 1,02 & 0,4420 & 0,4701 & 1,06 \\
\hline 19 & Ambon & $-3,6984$ & 128,1801 & 1,4370 & 1,0844 & 0,75 & 0,5130 & 0,3910 & 0,76 \\
\hline 20 & Manokwari & $-0,8545$ & 134,0567 & 1,4550 & 1,5835 & 1,09 & 0,5640 & 0,6376 & 1,13 \\
\hline 21 & Jayapura & $-2,5912$ & 140,6746 & 1,5000 & 1,5000 & 1,00 & 0,6000 & 0,6000 & 1,00 \\
\hline
\end{tabular}

Dibandingkan dengan nilai parameter percepatan spektra perioda pendek menurut SNI 1726:2012, nilai parameter percepatan spektra perioda pendek menurut SNI 1726:2019 di 12 kota, yaitu: Banda Aceh, Medan, Padang, Bengkulu, Palembang, Bandar Lampung, Jakarta, Yogyakarta, Surabaya, Mataram, Manado dan Manokwari, mengalami kenaikan dengan rasio antara 1,02-1,34; 1 kota, yaitu: Jayapura, tidak mengalami perubahan; dan 8 kota, yaitu: Bandung, Semarang, Denpasar, Kupang, Makassar, Kendari, Palu dan Ambon, ternyata malah mengalami penurunan dengan rasio berkisar antara 0,69-0,98.

Nilai parameter percepatan spektra perioda 1 detik menurut SNI 1726:2019 di 14 kota mengalami kenaikan dengan rasio berkisar antara 1,05-1,52, yaitu: Medan, Bengkulu, Palembang, Bandar Lampung, Jakarta, Bandung, Semarang, Yogyakarta, Surabaya, Denpasar, Mataram, Kupang, Manado, dan Manokwari; 2 kota, yaitu: Padang dan Jayapura, tidak mengalami perubahan; dan 5 kota, yaitu: Banda Aceh, Makassar, Kendari, Palu dan Ambon, mengalami penurunan dengan rasio antara 0,60-0,92, dibandingkan dengan nilai parameter percepatan spektra perioda 1 detik menurut SNI 1726:2012.

Tabel 2. Parameter Spektra Desain Perioda Pendek $S_{\mathrm{DS}}$ untuk 21 Kota di Indonesia

\begin{tabular}{|c|c|c|c|c|c|c|c|c|c|c|}
\hline \multirow{2}{*}{ No. } & \multirow{2}{*}{ Kota } & \multicolumn{3}{|c|}{ Tanah Keras (SC) } & \multicolumn{3}{|c|}{ Tanah Sedang (SD) } & \multicolumn{3}{|c|}{ Tanah Lunak (SE) } \\
\hline & & 1726:12 & 1726:19 & Rasio & 1726:12 & 1726:19 & Rasio & 1726:12 & 1726:19 & Rasio \\
\hline 1 & Banda Aceh & 0,906 & 1,202 & 1,33 & 0,906 & 1,002 & 1,11 & 0,815 & 0,801 & 0,98 \\
\hline 2 & Medan & 0,419 & 0,542 & 1,30 & 0,485 & 0,558 & 1,15 & 0,579 & 0,635 & 1,10 \\
\hline 3 & Padang & 0,927 & 1,164 & 1,26 & 0,927 & 0,970 & 1,05 & 0,835 & 0,793 & 0,95 \\
\hline 4 & Bengkulu & 0,747 & 1,200 & 1,61 & 0,786 & 1,000 & 1,27 & 0,673 & 0,800 & 1,19 \\
\hline 5 & Palembang & 0,210 & 0,254 & 1,21 & 0,278 & 0,306 & 1,10 & 0,430 & 0,446 & 1,04 \\
\hline 6 & $\begin{array}{l}\text { Bandar } \\
\text { Lampung }\end{array}$ & 0,545 & 0,692 & 1,27 & 0,596 & 0,665 & 1,12 & 0,602 & 0,697 & 1,16 \\
\hline 7 & Jakarta & 0,516 & 0,651 & 1,26 & 0,573 & 0,637 & 1,11 & 0,607 & 0,677 & 1,12 \\
\hline 8 & Bandung & 0,978 & 0,946 & 0,97 & 0,978 & 0,810 & 0,83 & 0,880 & 0,752 & 0,85 \\
\hline 9 & Semarang & 0,674 & 0,696 & 1,03 & 0,739 & 0,668 & 0,90 & 0,607 & 0,698 & 1,15 \\
\hline 10 & Yogyakarta & 0,722 & 0,886 & 1,23 & 0,770 & 0,780 & 1,01 & 0,650 & 0,749 & 1,15 \\
\hline 11 & Surabaya & 0,503 & 0,637 & 1,27 & 0,563 & 0,627 & 1,12 & 0,607 & 0,670 & 1,10 \\
\hline 12 & Denpasar & 0,657 & 0,766 & 1,17 & 0,722 & 0,713 & 0,99 & 0,604 & 0,724 & 1,20 \\
\hline 13 & Mataram & 0,650 & 0,833 & 1,28 & 0,714 & 0,752 & 1,05 & 0,607 & 0,741 & 1,22 \\
\hline 14 & Kupang & 0,742 & 0,840 & 1,13 & 0,783 & 0,756 & 0,97 & 0,668 & 0,742 & 1,11 \\
\hline 15 & Makassar & 0,252 & 0,191 & 0,76 & 0,325 & 0,235 & 0,72 & 0,481 & 0,353 & 0,73 \\
\hline 16 & Kendari & 0,590 & 0,561 & 0,95 & 0,645 & 0,573 & 0,89 & 0,611 & 0,642 & 1,05 \\
\hline 17 & Palu & 1,453 & 1,200 & 0,83 & 1,453 & 1,000 & 0,69 & 1,308 & 0,800 & 0,61 \\
\hline 18 & Manado & 0,690 & 0,842 & 1,22 & 0,749 & 0,757 & 1,01 & 0,621 & 0,742 & 1,20 \\
\hline
\end{tabular}




\begin{tabular}{|c|c|c|c|c|c|c|c|c|c|c|}
\hline \multirow{2}{*}{ No. } & \multirow{2}{*}{ Kota } & \multicolumn{3}{|c|}{ Tanah Keras (SC) } & \multicolumn{3}{|c|}{ Tanah Sedang (SD) } & \multicolumn{3}{|c|}{ Tanah Lunak (SE) } \\
\hline & & 1726:12 & $1726: 19$ & Rasio & $1726: 12$ & $1726: 19$ & Rasio & 1726:12 & 1726:19 & Rasio \\
\hline 19 & Ambon & 0,958 & 0,868 & 0,91 & 0,958 & 0,771 & 0,80 & 0,862 & 0,746 & 0,87 \\
\hline 20 & Manokwari & 0,970 & 267 & 21 & 0,970 & 1,056 & 1,09 & 0,873 & 0,845 & 0,97 \\
\hline 21 & Jayapura & 1,000 & 1,200 & 1,20 & 1,000 & 1,000 & 1,00 & 0,900 & 0,800 & 0,89 \\
\hline
\end{tabular}

Sesuai dengan nilai faktor amplifikasi $\mathrm{F}_{\mathrm{a}}$ dalam SNI 1726:2012 dan SNI 1726:2019, untuk nilai $S_{\mathrm{DS}}$ di kelas situs Tanah Keras (SC), 16 kota mengalami kenaikan dengan rasio 1,03-1,61, dan 5 kota mengalami penurunan dengan rasio berkisar 0,76-0,97. Di kelas situs Tanah Sedang (SD), 12 kota mengalami kenaikan dengan rasio 1,01-1,27, 1 kota tidak mengalami perubahan, dan 8 kota mengalami penurunan dengan rasio 0,69-0,99. Di kelas situs Tanah Lunak (SE), 13 kota mengalami kenaikan dengan rasio 1,04-1,22 dan 8 kota mengalami penurunan dengan rasio 0,61-0,98.

Dengan penerapan faktor amplifikasi $\mathrm{F}_{\mathrm{v}}$ sesuai SNI 1726:2012 dan SNI 1726:2019, untuk nilai $S_{\mathrm{D} 1}$ di kelas situs Tanah Keras (SC), 16 kota mengalami kenaikan dengan rasio 1,08-1,40, dan 5 kota mengalami penurunan dengan rasio 0,62-0,99. Di kelas situs Tanah Sedang (SD), 17 kota mengalami kenaikan dengan rasio 1,04-1,49 dan 4 kota mengalami penurunan dengan rasio 0,77-0,97. Di kelas situs Tanah Lunak (SE), 10 kota mengalami kenaikan dengan rasio 1,02-1,41, 1 kota tidak mengalami perubahan dan 10 kota mengalami penurunan dengan rasio berkisar 0,65-0,99.

Tabel 3. Parameter Spektra Desain Perioda 1 detik $S_{D 1}$ untuk 21 Kota di Indonesia

\begin{tabular}{|c|c|c|c|c|c|c|c|c|c|c|}
\hline \multirow{2}{*}{ No. } & \multirow{2}{*}{ Kota } & \multicolumn{3}{|c|}{ Tanah Keras (SC) } & \multicolumn{3}{|c|}{ Tanah Sedang (SD) } & \multicolumn{3}{|c|}{ Tanah Lunak (SE) } \\
\hline & & 1726:12 & 1726:19 & Rasio & 1726:12 & 1726:19 & Rasio & 1726:12 & 1726:19 & Rasio \\
\hline 1 & $\begin{array}{l}\text { Banda } \\
\text { Aceh }\end{array}$ & 0,564 & 0,560 & 0,99 & 0,651 & 0,680 & 1,04 & 1,042 & 0,800 & 0,77 \\
\hline 2 & Medan & 0,326 & 0,362 & 1,11 & 0,385 & 0,468 & 1,22 & 0,592 & 0,616 & 1,04 \\
\hline 3 & Padang & 0,520 & 0,560 & 1,08 & 0,600 & 0,680 & 1,13 & 0,960 & 0,800 & 0,83 \\
\hline 4 & Bengkulu & 0,438 & 0,560 & 1,28 & 0,505 & 0,680 & 1,35 & 0,808 & 0,800 & 0,99 \\
\hline 5 & Palembang & 0,179 & 0,250 & 1,40 & 0,234 & 0,350 & 1,49 & 0,362 & 0,508 & 1,41 \\
\hline 6 & $\begin{array}{l}\text { Bandar } \\
\text { Lampung }\end{array}$ & 0,314 & 0,429 & 1,37 & 0,374 & 0,535 & 1,43 & 0,578 & 0,670 & 1,16 \\
\hline 7 & Jakarta & 0,301 & 0,394 & 1,31 & 0,361 & 0,501 & 1,39 & 0,561 & 0,637 & 1,13 \\
\hline 8 & Bandung & 0,427 & 0,508 & 1,19 & 0,493 & 0,610 & 1,24 & 0,782 & 0,743 & 0,95 \\
\hline 9 & Semarang & 0,329 & 0,377 & 1,14 & 0,388 & 0,483 & 1,24 & 0,597 & 0,626 & 1,05 \\
\hline 10 & Yogyakarta & 0,378 & 0,500 & 1,32 & 0,432 & 0,600 & 1,39 & 0,651 & 0,734 & 1,13 \\
\hline 11 & Surabaya & 0,260 & 0,344 & 1,32 & 0,319 & 0,449 & 1,41 & 0,503 & 0,602 & 1,20 \\
\hline 12 & Denpasar & 0,345 & 0,396 & 1,15 & 0,403 & 0,503 & 1,25 & 0,614 & 0,638 & 1,04 \\
\hline 13 & Mataram & 0,362 & 0,406 & 1,12 & 0,418 & 0,512 & 1,23 & 0,631 & 0,646 & 1,02 \\
\hline 14 & Kupang & 0,296 & 0,375 & 1,27 & 0,356 & 0,481 & 1,35 & 0,554 & 0,625 & 1,13 \\
\hline 15 & Makassar & 0,157 & 0,108 & 0,69 & 0,211 & 0,171 & 0,81 & 0,320 & 0,297 & 0,93 \\
\hline 16 & Kendari & 0,324 & 0,200 & 0,62 & 0,384 & 0,294 & 0,77 & 0,591 & 0,440 & 0,75 \\
\hline 17 & Palu & 0,666 & 0,560 & 0,84 & 0,768 & 0,680 & 0,89 & 1,229 & 0,800 & 0,65 \\
\hline 18 & Manado & 0,400 & 0,470 & 1,17 & 0,459 & 0,573 & 1,25 & 0,707 & 0,708 & 1,00 \\
\hline 19 & Ambon & 0,445 & 0,391 & 0,88 & 0,513 & 0,498 & 0,97 & 0,821 & 0,635 & 0,77 \\
\hline 20 & Manokwari & 0,489 & 0,595 & 1,22 & 0,564 & 0,723 & 1,28 & 0,902 & 0,850 & 0,94 \\
\hline 21 & Jayapura & 0,520 & 0,560 & 1,08 & 0,600 & 0,680 & 1,13 & 0,960 & 0,800 & 0,83 \\
\hline
\end{tabular}




\subsection{Anomali Spektra Desain}

Selama ini para Perencana Struktur terbiasa dengan pola pikir bahwa nilai spektra desain untuk kelas situs Tanah Keras (SC), Sedang (SD) dan Lunak (SE) meningkat secara berurut. Jadi, semakin lunak tanahnya, maka semakin besar nilai spektra desainnya. Seperti SNI 031726-2002 (Badan Standardisasi Nasional, 2002) juga masih menganut paham ini. Ternyata adanya faktor amplifikasi $F_{a}$ dan $F_{v}$ dalam SNI 1726:2012 dan SNI 1726:2019 telah merubah urut-urutan tersebut sehingga kemudian disebut sebagai anomali.

Dari Tabel 2 dapat diketahui bahwa spektra desain perioda pendek ( $\mathrm{S}_{\mathrm{DS}}$ ) pada 21 kota terpilih dapat mengalami 4 kondisi sebagai berikut:

1. Normal : Spektra desain $\mathrm{SC}<\mathrm{SD}<\mathrm{SE}$

2. Anomali 1 : Spektra desain $\mathrm{SD}<\mathrm{SC}<\mathrm{SE}$

3. Anomali 2 : Spektra desain $\mathrm{SD}<\mathrm{SE}<\mathrm{SC}$

4. Anomali 3 : Spektra desain $\mathrm{SE}<\mathrm{SD}<\mathrm{SC}$

Ada 4 kota dengan kondisi normal, yaitu: Medan, Palembang, Makassar dan Kendari; 4 kota dengan kondisi anomali 1, yaitu: Bandar Lampung, Jakarta, Semarang dan Surabaya; 1 kota dengan kondisi anomali 2, yaitu: Denpasar; dan 12 kota dengan kondisi anomali 3, yaitu: Banda Aceh, Padang, Bengkulu, Bandung, Yogyakarta, Mataram, Kupang, Palu, Manado, Ambon, Manokwari dan Jayapura.

Sedangkan pada Tabel 3, spektra desain perioda 1 detik $\left(\mathrm{S}_{\mathrm{D} 1}\right)$ pada 21 kota terpilih tidak menunjukkan adanya anomali, yakni kondisi spektra desain $\mathrm{SC}<\mathrm{SD}<\mathrm{SE}$. Namun akibat

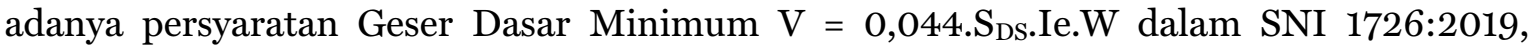
haruslah diperiksa apakah dampak anomali pada spektra desain perioda pendek juga berpengaruh pada bangunan bertingkat menengah dan tinggi.

\subsection{Studi Komparasi}

Dari sub bab perbandingan spektra desain diketahui beberapa kota di Indonesia mengalami kenaikan maupun penurunan nilai parameter spektra. Untuk melihat lebih jauh pengaruh penerapan SNI 1726:2019 terhadap desain struktur rangka momen beton bertulangan, maka dilakukan studi komparasi dengan memakai sampel model struktur bangunan gedung yang diasumsikan terletak di daerah yang mengalami kenaikan nilai parameter spektra.

\subsubsection{Perbandingan Gaya Gempa}

Selanjutnya ditinjau perencanaan struktur rangka momen bertingkat 5 yang diasumsikan terletak di kota Jakarta pada kondisi Tanah Lunak (SE) dan berfungsi sebagai hotel (kategori risiko II). Struktur yang ditinjau ditunjukkan pada Gambar 1 dengan jarak antar kolom arah $\mathrm{x}: 6 \mathrm{~m}$ dan jarak antar kolom arah y: $4 \mathrm{~m}$. Tebal pelat lantai $130 \mathrm{~mm}$, ukuran balok tipikal: $250 \times 500(\mathrm{~mm})$ dan $250 \times 400(\mathrm{~mm})$. Ukuran kolom tingkat-1 sampai dengan tingkat-5: $400 \times 500(\mathrm{~mm})$ dan tinggi antar lantai: $3,5 \mathrm{~m}$. Beban mati tambahan untuk atap: $1,06 \mathrm{kN} / \mathrm{m}^{2}$, sedangkan untuk lantai lainnya: $3,00 \mathrm{kN} / \mathrm{m}^{2}$. Beban hidup untuk atap: $1,00 \mathrm{kN} / \mathrm{m}^{2}$, sedangkan untuk lantai lainnya: $2,00 \mathrm{kN} / \mathrm{m}^{2}$. Perhitungan beban gempa sesuai SNI 1726:2012 dan SNI 1726:2019. 

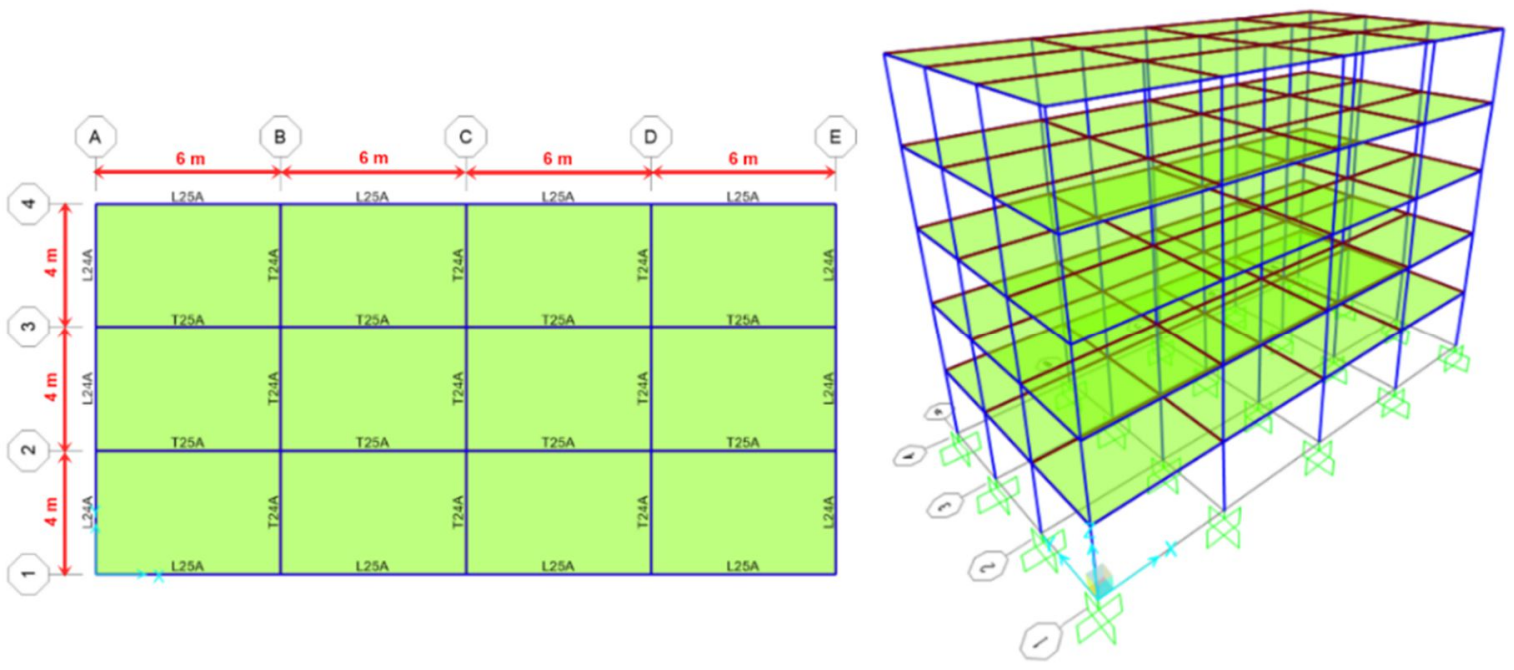

Gambar 1. Model Struktur Dalam Studi Komparasi

Tabel 4. Perbandingan Variabel Perencanaan Gempa Kota Jakarta Tanah Lunak

\begin{tabular}{lll}
\hline Variabel & SNI 1726:2012 & SNI 1726:2019 \\
\hline $\mathrm{S}_{\mathrm{DS}}$ & 0,607 & 0,677 \\
\hline $\mathrm{S}_{\mathrm{D} 1}$ & 0,561 & 0,637 \\
\hline $\mathrm{T}_{0}$ (detik) & 0,185 & 0,188 \\
\hline Ts (detik) & 0,924 & 0,940 \\
\hline KDS & $\mathrm{D}$ & $\mathrm{D}$ \\
\hline Sistem & SRPMK & SRPMK \\
Struktur & 8 & 8 \\
\hline $\mathrm{R}$ & 0,076 & 0,085 \\
\hline $\mathrm{C}_{\mathrm{s}}$ & 1.024 & 1.142 \\
\hline $\mathrm{V}(\mathrm{kN})$ &
\end{tabular}

Tabel 5. Perbandingan Gaya Gempa pada Setiap Lantai

\begin{tabular}{lllll}
\hline \multirow{2}{*}{ Lantai } & \multicolumn{2}{l}{ SNI 1726:2012 } & \multicolumn{2}{l}{ SNI 1726:2019 } \\
\cline { 2 - 5 } & Fx $(\mathrm{kN})$ & Fy $(\mathrm{kN})$ & Fx $(\mathrm{kN})$ & Fy $(\mathbf{k N})$ \\
\hline 5 & 198 & 205 & 255 & 269 \\
\hline 4 & 262 & 261 & 338 & 342 \\
\hline 3 & 208 & 203 & 268 & 266 \\
\hline 2 & 146 & 139 & 189 & 182 \\
\hline 1 & 72 & 63 & 93 & 83 \\
\hline Base Shear & 886 & 870 & 1.142 & 1.142 \\
\hline
\end{tabular}

\subsubsection{Evaluasi Kinerja Struktur Terhadap Gempa 2012}

Untuk gedung arah $\mathrm{x}$ dan $\mathrm{y}$, dilakukan analisis pushover untuk mendapatkan kurva kapasitas dalam betuk gaya geser dasar $\left(\mathrm{V}_{\mathrm{b}}\right)$ terhadap perpindahan lantai atap $\left(\Delta_{\mathrm{atap}}\right)$. Selanjutnya, kurva kapasitas dan spektrum respons gempa 2012 dikonversi menjadi format ADRS. Setelah konversi dilakukan, spektrum respons direduksi dengan faktor $\mathrm{SR}_{\mathrm{A}}$ dan $\mathrm{SR}_{\mathrm{V}}$ sesuai ATC-40 dan selanjutnya dapat disatukan (superimposed) untuk mendapatkan titik 
kinerja. Setelah dilakukan iterasi, titik kinerja diketahui, untuk gedung arah $\mathrm{x}$ berada pada titik $0,297 \mathrm{~m}$ dan $2.945,84 \mathrm{kN}$, sedangkan gedung arah y berada pada titik $0,334 \mathrm{~m}$ dan $2.575,19 \mathrm{kN}$ (Gambar 2 dan Gambar 3).

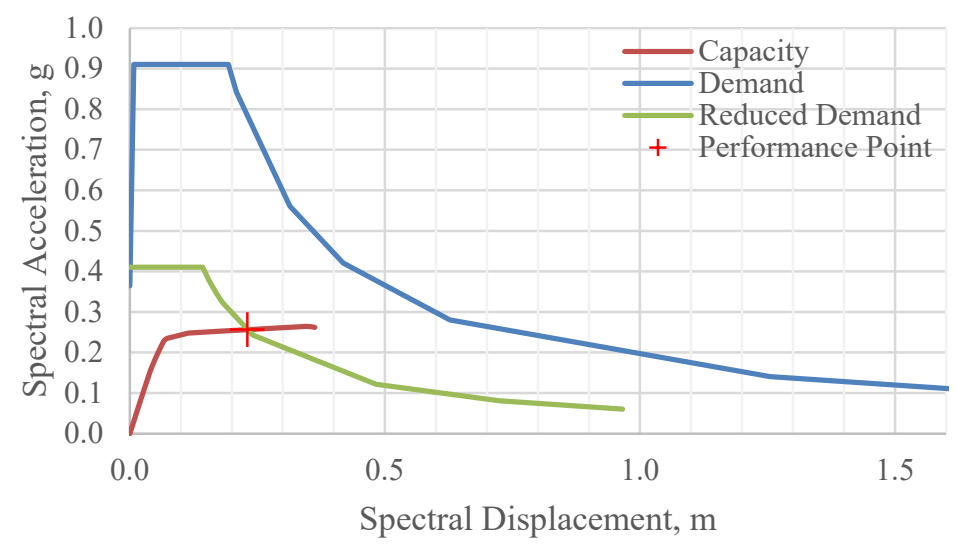

Gambar 2. Titik Kinerja Gedung Arah X (Gempa 2012)

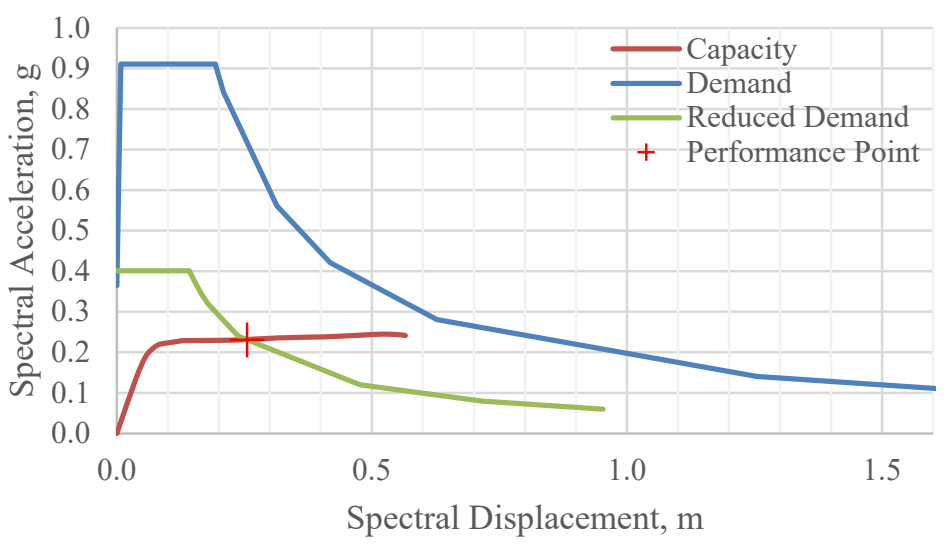

Gambar 3. Titik Kinerja Gedung Arah Y (Gempa 2012)

Selain itu, perlu juga dianalisis level kinerja elemen pada titik kinerja, yakni harus tidak ada elemen yang memenuhi level kinerja Collapse Prevention (CP). Terlihat pada Gambar 4 dan Gambar 5 tidak ada elemen saat berada di titik kinerja yang memiliki level kinerja CP. Oleh sebab itu, perilaku dan kinerja elemen pada saat berada di titik kinerja adalah baik. 


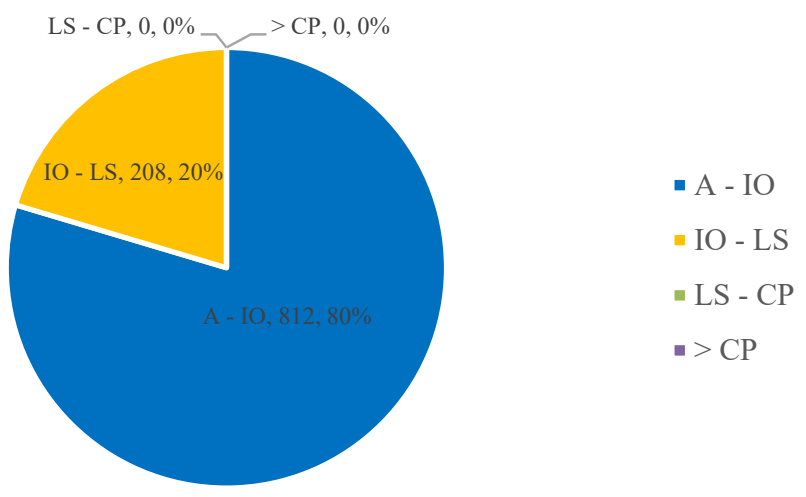

Gambar 4. Level Kinerja Elemen Struktur Gedung Arah X (Gempa 2012)

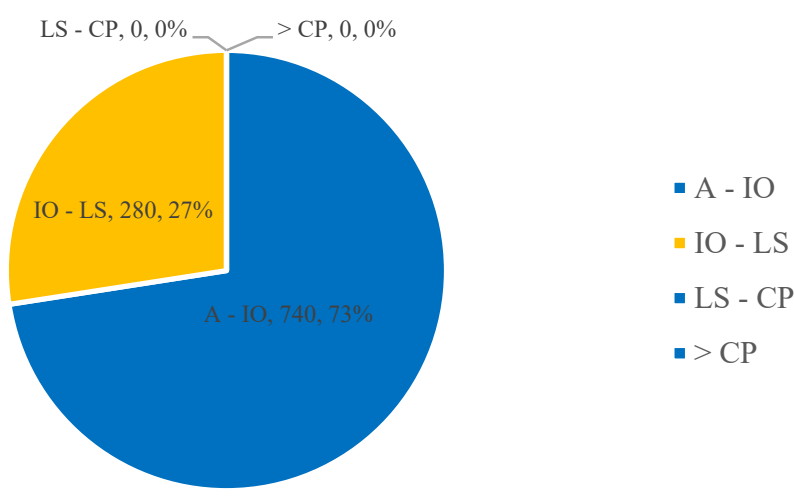

Gambar 5. Level Kinerja Elemen Struktur Gedung Arah Y (Gempa 2012)

Level kinerja struktur ditentukan berdasarkan Tabel 11-2 dalam ATC-40. Kinerja struktur ditentukan berdasarkan rasio nilai perpindahan atap saat berada di titik kinerja dengan tinggi total bangunan.

Untuk gedung arah $\mathrm{x}$ :

$$
0,010<\frac{\Delta_{\mathrm{p}}}{\mathrm{H}_{\text {tot }}}=\frac{0,297}{17,5}=0,017<0,020
$$

Untuk gedung arah y:

$$
0,010<\frac{\Delta_{\mathrm{p}}}{\mathrm{H}_{\text {tot }}}=\frac{0,334}{17,5}=0,019<0,020
$$


Dapat disimpulkan bahwa level kinerja struktur gedung arah x dan y adalah Damage Control/Life Safety, telah sesuai dengan tujuan perencanaan struktur umumnya.

\subsubsection{Evaluasi Kinerja Struktur Terhadap Gempa 2019}

Langkah yang sama juga dilakukan seperti evaluasi kinerja struktur terhadap gempa 2012. Analisis pushover dilakukan terhadap gedung arah $\mathrm{x}$ dan $\mathrm{y}$ untuk mendapatkan kurva kapasitas. Selanjutnya, kurva kapasitas dan spektrum respons gempa 2019 dikonversi menjadi format ADRS. Kemudian, spektrum respons direduksi dengan faktor $\mathrm{SR}_{\mathrm{A}}$ dan $\mathrm{SR}_{V}$ sesuai ATC-40 dan selanjutnya dapat disatukan (superimposed) untuk mendapatkan titik kinerja. Setelah dilakukan iterasi, titik kinerja diketahui, untuk gedung arah $\mathrm{x}$ berada pada titik $0,378 \mathrm{~m}$ dan $2.991,69 \mathrm{kN}$, sedangkan gedung arah y berada pada titik 0,441 $\mathrm{m}$ dan $2.630,94 \mathrm{kN}$ (Gambar 6 dan Gambar 7).

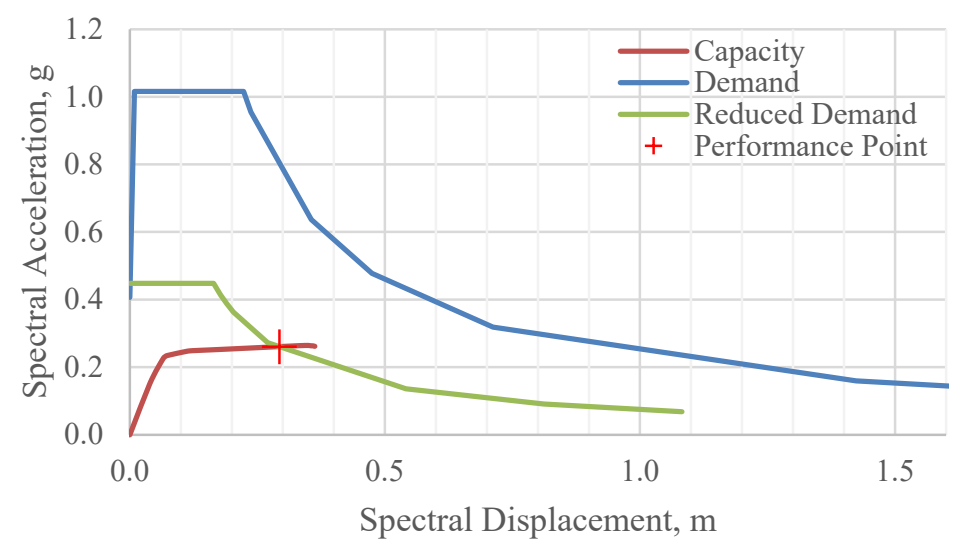

Gambar 6. Titik Kinerja Gedung Arah X (Gempa 2019)

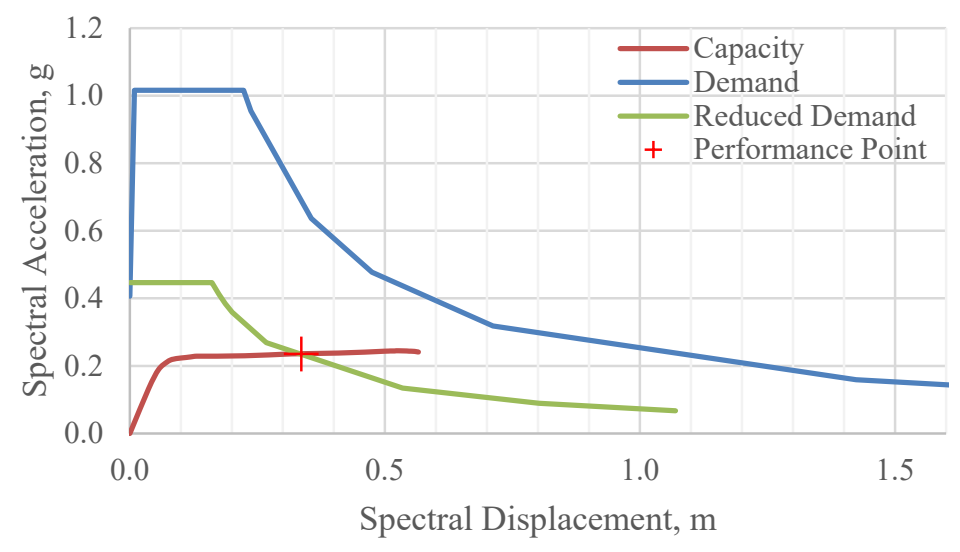

Gambar 7. Titik Kinerja Gedung Arah Y (Gempa 2019)

Level kinerja elemen pada titik kinerja juga perlu dianalisis, yakni harus tidak ada elemen yang memenuhi level kinerja Collapse Prevention (CP). Terlihat pada Gambar 8, ada sekitar 168 hinges dan pada Gambar 9, ada sekitar 56 hinges yang memiliki level kinerja LS - CP saat berada di titik kinerja. Oleh sebab itu, perilaku dan kinerja elemen pada saat berada di titik kinerja adalah tidak baik. 


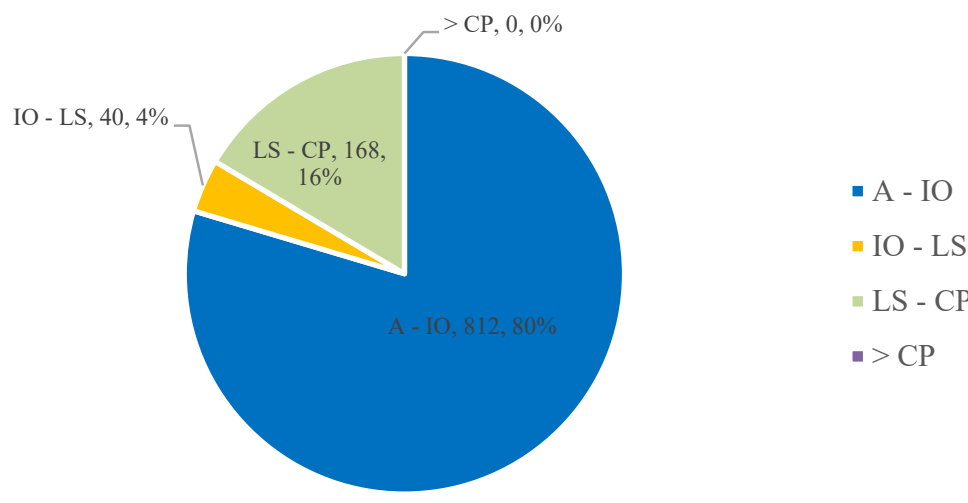

Gambar 8. Level Kinerja Elemen Struktur Gedung Arah X (Gempa 2019)

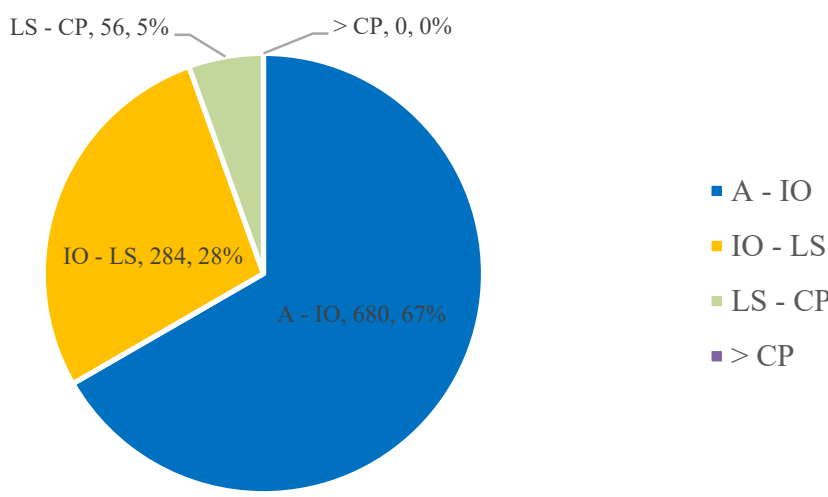

Gambar 9. Level Kinerja Elemen Struktur Gedung Arah Y (Gempa 2019)

Kinerja struktur secara global ditentukan berdasarkan rasio nilai perpindahan atap saat berada di titik kinerja dengan tinggi total bangunan. Level kinerja struktur ditentukan berdasarkan Tabel 11-2 dalam ATC-40.

Untuk gedung arah $\mathrm{x}$ :

$$
\frac{\Delta_{\mathrm{p}}}{\mathrm{H}_{\text {tot }}}=\frac{0,378}{17,5}=0,022>0,020
$$

Untuk gedung arah y:

$$
\frac{\Delta_{\mathrm{p}}}{\mathrm{H}_{\text {tot }}}=\frac{0,441}{17,5}=0,025>0,020
$$

Dapat disimpulkan bahwa level kinerja struktur gedung arah $\mathrm{x}$ dan y saat dikenai gempa 2019 adalah Collapse Prevention/Structural Stability. 


\section{KESIMPULAN}

Berdasarkan hasil penelitian yang telah dilakukan, didapatkan beberapa kesimpulan sebagai berikut:

1. Pembaruan SNI 1726 menyebabkan spektra desain dari 21 kota terpilih, kebanyakan mengalami kenaikan, walaupun tidak sedikit yang mengalami penurunan dan ada pula yang tetap. Penerapan SNI 1726:2019 (faktor amplifikasi $\mathrm{F}_{\mathrm{a}}$ ) juga menyebabkan adanya 3 kemungkinan kondisi anomali di kota-kota yang terletak di daerah rawan gempa dengan $\mathrm{S}_{\mathrm{S}}$ di atas $0,75 \mathrm{~g}$. Meskipun anomali hanya terjadi pada spektra desain perioda pendek yang umumnya berlaku untuk bangunan bertingkat rendah, namun akibat adanya persyaratan Geser Dasar Minimum haruslah diperiksa apakah dampaknya juga berpengaruh pada bangunan bertingkat menengah dan tinggi.

2. Ada 2 faktor penyebab naiknya gaya gempa pada SNI 1726:2019 yaitu: kenaikan parameter spektra desain $\left(\mathrm{S}_{\mathrm{DS}}, \mathrm{S}_{\mathrm{D} 1}\right)$ dan kenaikan faktor skala dinamik yang mulanya $85 \% \mathrm{~V}_{\mathrm{b}}$ statik pada SNI 1726:2012 menjadi 100\% Vb statik. Sekalipun terjadi penurunan parameter spektra desain, akibat adanya kenaikan faktor skala dinamik pada SNI 1726:2019, maka tetap perlu adanya peninjauan kembali terhadap bangunan yang terbangun menggunakan SNI 1726:2012.

3. Pada model gedung studi komparasi terjadi kenaikan base shear desain sebesar $128,93 \%$ (886 kN ke $1.142 \mathrm{kN})$ untuk arah $\mathrm{x}$ dan $131,23 \%(870 \mathrm{kN}$ ke $1.142 \mathrm{kN})$ untuk arah $\mathrm{y}$. Kenaikan ini kurang lebih sama dengan nilai kenaikan rasio parameter spektra $\mathrm{S}_{\mathrm{DS}}$ dikalikan rasio kenaikan faktor skala dinamik.

4. Hasil evaluasi kinerja dari gedung yang didesain terhadap SNI 1726:2012 menunjukkan kinerja yang baik, dimana tidak ada sendi plastis yang mencapai level Collapse Prevention pada titik kinerjanya dan secara global kinerja struktur adalah Life Safety.

5. Akibat diberlakukan/diterapkannya SNI 1726:2019, bangunan gedung yang sebelumnya didesain menggunakan SNI 1726:2012 mengalami penurunan kinerja dari Life Safety menjadi Collapse Prevention/Structural Stability.

\section{DAFTAR PUSTAKA}

American Society of Civil Engineers. (2017). Minimum Design Loads and Associated Criteria for Buildings and Other Structures (ASCE/SEI 7-16). asce.

Applied Technology Council. (1996). Seismic Evaluation and Retrofit of Concrete Buildings (ATC-4O).

Badan Standardisasi Nasional. (2002). Tata Cara Perencanaan Ketahanan Gempa untuk Bangunan Gedung (SNI 03-1726-2002). BSN.

Badan Standardisasi Nasional. (2012). Tata Cara Perencanaan Ketahanan Gempa untuk Struktur Bangunan Gedung dan Non Gedung (SNI 1726:2012). BSN.

Badan Standardisasi Nasional. (2019). Tata Cara Perencanaan Ketahanan Gempa untuk Struktur Bangunan Gedung dan Non Gedung (SNI 1726:2019). BSN.

Building Seismic Safety Council. (2015). Recommended Seismic Provision for New Buildings and Other Structures (FEMA 1050). FEMA.

Irsyam, M., Widiyanto, S., Natawidjaja, D. H., Meilano, I., Rudyanto, A., Hidayati, S., Triyoso, W., Hanifa, N. R., Djarwadi, D., Faizal, L., \& Sunarjito. (2017). Peta Sumber dan Bahaya Gempa Indonesia Tahun 2017. Litbang Kementerian Pekerjaan Umum.

PuSGen. (2010). Aplikasi Desain Spektra Indonesia 2010. Puslitbang Perumahan dan Pemukiman.

PuSGen. (2021). Aplikasi Desain Spektra Indonesia 2021. Direktorat Jenderal Cipta Karya.

Sutjipto, S., \& Sumeru, I. (2019). Comparison of the RSNI 1726:2018 and the SNI 1726:2012 design response spectra of 17 major cities in Indonesia. IOP Conference Series: Materials Science and Engineering, 650, 012032. https://doi.org/10.1088/1757-899X/650/1/012032 